\title{
TYPOLOGY OF E-LEARNING TOOLS FOR FOREIGN LANGUAGES LEARNING
}

\author{
Dana Bartosh ${ }^{1}$, Natalia Galskova ${ }^{2}$, \\ Maria Kharlamova ${ }^{3}$, Elena Stoyanova ${ }^{4}$
}

\begin{abstract}
The paper is devoted to the issue of typologisation of e-learning tools for educational purposes in the sphere of foreign languages learning. The analysis of the previous research in the field leads to the conclusion that all digital tools in the learning environment can be subdivided according to their nature and the function they perform in the process of foreign languages learning.

Analysis reveals that all e-learning tools are based on information and communication technology used for transmission of information and organization of communication. Modern computer tools and software can significantly intensify the learning and teaching process. The use of computer-aided learning tools in language education, taking into account their typological characteristics and in accordance with specific educational tasks, allows for a full realization of their specific linguistic and didactic functions.
\end{abstract}

Keywords: e-learning, foreign language, technology of foreign languages e-learning, e-learning tool, language education

\section{Introduction}

Nowadays, the system of language education actively explores methodological issues of the use of new multimediaand hypermedia technologies, develops various aspects of Internet resources use in order to develop foreign communicative competence of students, builds educational systems for foreign languages, based on information and communication and/or network technologies in the system of secondary and higher schools. Despite the fact of having a wide range of studies and great attention paid to the didactic possibilities of modern

1. Associate Professor, Doctor of pedagogical sciences at Pushkin State Russian Language Institute, Faculty of Advanced Education, Moscow, Russia, e-mail: bartosch@,inbox.ru

2. Professor, Doctor of pedagogical sciences at Moscow State Regional University, Department of Linguodidactics, Moscow, Russia, e-mail: galskova@mail.ru

3. Associate Professor, Candidate of pedagogical sciences at Pushkin State Russian Language Institute, Department of Modern Educational Technologies in the Faculty of Advanced Education, Moscow, Russia, e-mail: kharlamariya@yandex.ru

4. Professor, PhD at Shumen University, Department of Russian Studies, Shumen, Bulgaria, e-mail: elvikstoyanova@shu.bg 
e-learning tools, methods of foreign languages learning are still lacking in their reasonable classification, taking into account the specifics of the subject "foreign language" relating to the tasks set by the state educational standards for the system of language teaching. This situation often prevents teachers from making the right choice of e-learning technology, which, of course, does not contribute to the effectiveness of linguistic and cultural training of students.

The aim of this article is to systematize e-learning tools currently applied in language teaching and define their typological characteristics.

Nowadays no one objects to the fact that any e-learning tool should be used only in cases where the learning process is not effective enough without this tool. Therefore, it is so important to identify the linguistic and didactic potential of each typological group of these tools. This will contribute to teachers 'understanding of what each computer-mediated learning tool can bring to the learning process and how it should be used in this process.

\section{Previous research in the field}

The analysis of the literature allows considering e-learning of foreign languages as a certain form of organization of the educational process and control, i.e. "the way, the nature of interaction between the teacher and students, between students, and between students and the material under study" (Zagvyazinsky, 2001, p. 81). So, e-learning tools, performing primarily the supporting role, are a set of didactic materials/manuals/tasks and technical devices, the use of which is designed to optimize, as far as possible, foreign language learning and manage the activities of students to master the language. And from this point of view, information and communication technologies that are understood as "news channels, and software tools for the creation, collection, storage, transfer, handling, use of information" (Sysoev, 2012, p. 32-33), and e-learning tools can be seen as synonyms.

Computerization, as a feature of modern language education, explains the rising interest of scientists and practitioners in the problems of computer-mediated teaching disciplines, including foreign languages. As the result of this interest there are a lot of conceptions of ICT implementation, particularly of Internet resources in teaching $\backslash$ learning a foreign language. A large number of special studies are devoted to the analysis of the process of computerization in education and the didactic properties of digital learning tools in school, and in teacher training (Babkina, 2017; Baur, 1999; Kochenderfer, 2013; Koshelaeva, 2010; Martiny, 2009; Moser, 2001, 2003; Paveleva, 2010; Petrisheva, 2011; Platten, 2003; Robert, 2005; Schäfner, 2009; Stöcklin, 2012; Sysoev, 2013; Urban-Woldron, 2008; Zaec, 2017).

Achievement of educational results based on using of electronic training technologies is proved by experts by providing evidence. One of them is the 
great importance that digital tools and technologies have in the life of a modern student (Zaets, 2017). "The future belongs to young people and we cannot ignore their reality, which is saturated with electronic technologies" (Stöcklin, 2012). In didactics, the term "digital natives", meaning "electronic/digital native speakers", has long been used to refer to today's young people. "Our students have changed radically. [...] They spend their entire lives surrounded by and using computers, videogames, digital music players, video cams, cell phones, and all the other toys and tools of the digital age. [...] as a result of this ubiquitous environment and the sheer volume of their interaction with it, today's students think and process information in a fundamentally different way from their predecessors" (Prensky, 2001).

The next argument in favor of the use of ICT in the educational process is the possibility of creating conditions for personal development using these technologies in four important areas: valuable meanings, self-identification, competence and personal qualities (Bartosh, 2017, pp. 13-19). Electronic technologies provide multimedia and interactive learning environments, contribute to the development of independent and autonomous activities (Schäfner, 2009), help students to achieve their full development potential" (Kathleen, 2003), provide access to relevant authentic information directly from the country of the language under study (Platten, 2003, p. 175). They support authentic communication in chats and forums, which contributes to the development of communication skills more effectively than role-playing "as if-situations" (Martiny, 2009). They create unique conditions for familiarizing students with the cultural diversity of the communities of the foreign countries of the language under study (Koshelyaeva, 2010; Paveleva, 2010; Petrishcheva, 2011, etc.).

Taking into account all the information mentioned above, the appeal to e-learning in foreign languages has a great motivating effect for students. And educational motivation, in turn, causes the emergence of such constructs as selfeffectiveness, self-assessment, self-regulation, self-perception, setting goals and objectives in the context of educational activities (Helmke \& Weinert, 1997). Based on our own study (in particular, on the analytical IMST project) and some other researchers (Urban-Woldron, 2008) it is possible to draw a conclusion that computer training under certain conditions can increase the motivation to learn the subject through interactive activity with educational material, and also provide opportunity of individual learning.

Thus, e-learning can now be considered an integral part of the learning process of any subject, including a foreign language.

However, an analysis of the available work in the field of interest shows that most of the research is devoted to the use of information and communication 
technologies in higher education, and that there is no common understanding among researchers of a number of issues, for example:

- What is meant by e-learning technologies?

- What is their didactic resource and under what conditions the resource can be implemented in school?

- What e-learning technologies can fully implement the requirements of state educational standards for the quality of language education?

- How does the educational environment change through the use of e-learning technologies for foreign languages?

There are a large number of unresolved issues, because the topic under consideration is extremely complex: on the one hand, the multidimensional nature of the communication space created with the help of computer technologies, and, on the other, the multidimensional nature of the educational space where these technologies are actively implemented. At the same time, the use of these technologies implies not only the existence of the appropriate base, but also the profound knowledge of computer programs, components of the Internet by teacher and students and their understanding of what each component can bring to the learning process, and how it should be used in the learning process.

\section{Materials and methods}

Research done by the authors of the article on the issue of introduction into the educational space of modern school tools of e-learning in order to improve the effectiveness of the educational process in foreign languages was carried out by taking into account different perspectives:

1) in the context of certain linguistic and cultures situation and the tasks of the society;

2) from the point of view of the requirements of Federal state educational standards of school education to the quality of language education;

3) based on the latest results of methodological science, including methodological concepts of e-learning;

4) taking into account the linguistic and didactic specifics of modern computer multimedia technologies and their potential as a means of improving the effectiveness of the educational process in foreign languages.

During the research period, the authors of the article analyzed some theoretical and practical works of modern Russian and foreign experts, dedicated to exploring the use of information and communication technologies in teaching foreign languages, the conditions of their effective use, and didactic properties 
of these technologies (Babkin 2017; Baur, 1999; Ezhikov, 2013; Hughes, 2005; Kerres, 2013; Kochenderfer, 2013; Koshelaeva 2010, 2009; Martiny, 2009; Moser 2001, 2003; Ovchinnikova, 2010; Pavelyev \& Petrisheva, 2011; Platten \& Schäfner, 2009; Robert, 2005; Stöcklin, 2012; Sysoev, 2013; Urban-Woldron, 2008; Zayets, 2017). On this basis, the use of systematic typological approaches helped to identify, compare and generalize the linguistic and didactic possibilities of various e-learning tools, and carry out their classification according to their typological characteristics.

\section{Data Analysis}

All e-learning tools (multimedia, including interactive whiteboard, computer training programs, electronic textbooks, Internet resources, computer telecommunications, etc.) can be typologized based on two features. The first one is the functions performed by electronic tools in the educational process, the second one - the nature of the digital tool. Each classification group has its own didactic resource that provides the tools and technologies of foreign language e-learning with their characteristics. One should notice that in certain circumstances the same learning tool may belong to different groups.

In the first classification group, based on the functional load, all e-learning tools can be divided into three types: 1) demonstration; 2) information; 3) providing communication.

The first type, demonstration, is represented by such technological tools as computer presentations and interactive whiteboard. In the educational process of foreign language learning, they provide the audio-visual presentation of learning content, for example, due to the demonstration of linguistic units and the context of their use, illustrate the regional geographic information, etc. The use of these e-learning tools contributes to the visualization of information, and, as a result, shift "of focus from the illustrative functions" to the development of students' cognitive abilities and critical thinking, creation of mental images in the human mind in the process of semantic processing of the received information (Babkina, 2017, p. 16). The interactive whiteboard helps to implement not only the principle of clarity, but to intensify language learning by facilitating access to information and increasing the speed of its flow, touch control (time saving, easy to use), record, select, and edit in real time, a combination of features of the tool and the data carrier. Due to modern technological solutions of computer presentations and interactive whiteboard, one can acquire a high degree of interactivity and multimedia, in particular, when installing the LP Suite tools in the form of add-ins for PowerPoint.

As for information e-learning tools which belong to second type, they include authentic (for example, websites of Newspapers, magazines, museums, cities, 
individuals, etc.) and learning (resources created directly for learning purposes) Internet resources. Regardless of their nature, this type of resources is designed (if they are properly implemented in foreign language learning) to form students' individual style of activity, a culture of self-determination, to stimulate their personal enhancement. Work with Internet resources helps the user to form the ability to find, summarize, and critically evaluate information, to interpret it according to given task, to develop skills of reading, listening based on authentic audio texts, monologue and dialogue utterance on the basis of problem discussion of Internet data, as well as enrichment of their lexicon with new lexis that is found in authentic texts on the Internet, to familiarize with the socio-cultural aspect of the language. The use of the Internet expands the range of authentic communicative situations in the language under study, increases the motivation to learn a foreign language, and provides each student with the opportunity to independently choose an individual plan for language learning, perform creative, project tasks. With the help of Internet resources, one can implement a variety of educational technologies or Internet technologies. These include, for example, distance learning, online support for a traditional course, online support of the project and research activities etc.

As for learning Internet resources, they can be subdivided into:

- "Text, audio-visual materials on various topics aimed at forming of foreign language communicative competence and developing communicative and cognitive skills of students to search, select, classify, analyze and summarize information" (Sysoev, 2010, p. 42). These are authentic resources that are selected and didactically "interpreted" by the teacher: hotlist or a list of links to text Internet resources that should be studied; multimedia scrapbook or a list of links to multimedia resources: text sites, photos, audio files and video clips, graphic information and virtual tours; treasure hunt, i.e., a list of links to various sites on the topic under study, equipped with questions; subject sampler - a list of links to text and multimedia materials on the Internet, having studied which, the students need to answer questions, express and back up their own opinion on the subject under study; web quest or a list of links to multimedia and text resources, formulated questions by sections, the task of forming their own opinions and a general question of argumentative nature, organization of projects with involvement of all students and using Internet resources (Sysoev, 2010, pp. 42-44).

- Resources that are created by the teacher, such as personal websites or online courses. The websites created by the teacher can be very useful in their work, because the information they contain is structured according to their educational needs and their style of teaching, students' characteristics, and program requirements. Same as above, the pages of the website can be hotlists, web quests and other educational Internet resources, as well 
as links to pages that allow you to assess the level of students' language proficiency (language tests), textbooks and audiovisual applications, various presentations, etc.

As for networking online courses, they can include all the materials that are essential for teaching, and can be both autonomous, used for distance learning, and integrated into the face-to-face learning process, for example, the materials of separate modules (sections) of the course, used for training certain aspects of the language and types of speech activity or having a complex nature, as is the role-play (Ovchinnikova \& Akimova, 2009).

- Finally, the third type of e-learning tools includes the ones which provide communication on the web in a foreign language and are part of the tools based on their purpose of use. These include tools for synchronous and asynchronous communication. The first suggest the instant response of the partner user, the second-delayed one. One should notice, however, that modern messaging programs (messengers) often combine the capabilities of these two types of communication.

Taking into account the focus of the subject "foreign language" on the formation of students' ability to show a certain level of communication in a foreign language, the use of messengers in the educational process (for example, WhatsApp, Viber, Skype, etc.), chats, forums, means of Internet video communication, blogs, wiki, podcasts, YouTube, etc. seems very logical. The use of these tools allows the learner to develop skills in all types of speech activities, such as reading, writing (reading and commenting on records, wiki), listening (watching videos, audio podcasts), writing and speaking (creating your own videos, filling out blog pages or commenting on other people's work, etc.). In the system of teaching/learning foreign languages, this virtual communication means the interaction of subjects of the educational process with their partners at a distance, for example, interaction on joint projects, including telecommunications, exchange of educational information (between the teacher and students, between students or groups of students), quick access to electronic resources, etc.

The second classification group of e-learning tools is allocated in terms of the nature/specifics of the technical tools used. These are the so-called multimedia and information and communication tools (ICTs). One should notice that in literature, multimedia and information and communication tools are often inter-substituting concepts. We can partially agree on that, but there are also differences. If multimedia is computer tools (means) which, in addition to text way of presenting information, allow the user to get information through all possible channels of information perception: audio, video, animation, 3D image, etc., then ICT refers to "information channels and software for creation, 
collection, storage, transfer, handling, use of information" (Sysoev, 2012, pp. 32-33).

\section{Results and Key Findings}

ICT is synonymous with the concept of "electronic technology", since we are talking about technical possibilities to perform wireless communication, develop interfaces, visualize, convert, organize, and update information, to perform interaction of users (Robert, 2005). At the same time, the term "information technology" is broader than "computer technology", and the inclusion of such a communication component in the name of ICT is due to a change in the evolutionary stage in the development of the information society and the expansion of the use of the Internet network not only for finding the necessary information, but also for communication in the virtual world. At the same time, if we are talking about a certain set of ways and methods of using, for example, multimedia, in this case we can refer to multimedia technologies.

The very name of each considered type of electronic means (tools) includes linguistic and didactic sense. Thus, working with multimedia makes it possible to perceive information while using several organs of sense at the same time, to receive integrated presentation of any audiovisual information on the computer screen and implement interactive cooperation of user with the computer system. At the same time, multimedia, through the integration of text, sound, and image, provides a complex effect on the student and contributes to his virtual immersion into the language environment. This significantly changes the way of assimilating and assigning information: the rejection of linear perception in favor of greater "freedom of movement" in the information space where media resources are usually connected.

Among the media an important place is occupied by multimedia programs (Kochenderfer, 2013), "a synchronous online video communication" (Ezhikov, 2013), various simulating programs based on the logic of quests, etc. These tools have a high linguistic and didactic potential, according to which they, by creating an authentic language environment and offering a variety of authentic material, contribute to the development of students' socio-cultural competence, provide an opportunity to develop different types of foreign language activities, and have a positive impact on the emotional sphere of students.

The proposed classification of e-learning tools should help the teacher to make the right choice of e-learning technology, taking into account its educational objectives and characteristics of the group of students. Systematization of computer learning tools, describing their typological characteristics, makes the whole spectrum of modern electronic technologies and their capabilities to improve the effectiveness of linguistic and cultural training of students more evident for teachers. At the same time, there is a problem - the readiness and 
ability of modern teachers to use these technologies. Thus, the J. Hughes (2005) denotes three possible functions of computer in the classroom: substitution, amplification, transformation. If electronic tools are used to replace something, in his opinion, neither educational activity nor educational purpose changes. Learning will take place in a standard way, including instructions and subsequent reproduction, but with a slight difference that the role of the teacher will be performed by the computer. When using electronic technology for enhancement, certain tasks can be performed faster and more efficiently. If the electronic tools are used for transformation, they can contribute to changing the educational process and its modernization: can change educational content, forms of work, the role of the teacher, and ways to solve the problems of students. (Hughes, 2005, pp. 280-281).

The essence of the transformation process was accurately expressed by German researcher H. Schelhowe (2009). He describes 4 forms of the educational process when working with media mediated information. The first concerns a simple reference to individual news and knowledge. The second involves studying by students of more complex issues on the basis of didactic material and thus familiarizing with a certain culture. In the third form of the educational process involves socialization and enculturation of the user, in the fourth - the development of personality and identity takes place (Schelhowe, 2009, p. 13). If we talk about the process of development of student's personality, namely value meanings, self-identification, competencies and personal qualities, the mentioned above by $\mathrm{H}$. Schelhowe first and second forms of the learning process are insufficient. It is a question of professional multimedia language competence of a foreign language teacher as their ability and readiness for successful professional activity on teaching a foreign language with the use of ICT and multimedia technology. Based on the analysis of numerous studies, it was proved that the success or failure of the lesson does not depend on the use of a computer or other electronic tools, but on the didactic concept, on how the potential of electronic means was used in relation to a particular lesson. Electronic means alone cannot be well or poorly suited for learning, only their preparation and appropriate use can contribute to the achievement of the required effect (Kerres, 2013, p. 585). This point of view is shared by many researchers: "the lesson with using a computer is not good only because new technologies have been used" (Bauer, 1999, p. 15), "didactic efficiency is achieved only when new technologies create something more and different from what is in ordinary lessons with traditional means of learning" (Moser, 2001, p. 420). Thus, the teacher remains one of the central figures of the educational process, which reveals the possibility and potential of electronic means of education, but on the other hand it puts in special requirements on the teacher. Teachers should be central participants in and builders of the future of technology in education, not solely the recipients of decisions made by others, either in the area of training or 
in tool design. Specifically, they should be supported and encouraged to adapt computers to their own and their students' purposes, to explore the ways in which technologies can alter what happens in the classroom, and to share what they do and what "works" with other teachers (Sheingold \& Endreweit, 1987, p. 79).

\section{Conclusion}

The research provides some clarifications on the conceptual and terminological apparatus of the theory of e-learning and classifying the technology of foreign languages e-learning in accordance with their functions and nature. The division of technologies by functions and specific features of their use reflects the linguistic and didactic potential of these technologies in terms of the effectiveness of the educational process, as well as their compliance with the requirements of modern standards. The specifics of each technology's group in relation to the field of teachingllearning foreign languages at school, describes their place and role in the overall focus on the creation of a special information and communication learning environment as a holistic, open, accessible, multifunctional and interactive system.

The authors consistently support the understanding of the e-learning technology as a certain set of methods and methodologies of teaching a foreign language, implemented with the help of computer tools and ICT. In the offered classification all e-learning tools belong to additional or supporting educational materials that in turn actualize a question of teacher's competence in using e-learning technologies for the purpose of creation of the computer-mediated educational environment.

Thus, the appropriate material, technical and methodological basis, as well as the ability to use it, can ensure the effective integration of e-learning technologies into the educational process of foreign languages learning and contribute to improving the quality of language education in general.

\section{References:}

Babkina, E. V. (2017). Kognitivnaja vizualizacija pri obuchenii professionalno-orientirovannomu chteniju studentov tehnicheskih specialnostej v uslovijah multimedijnogo klassa. In Sozdanie virtualnogo mezhkulturnogo obrazovatelnogo prostranstva sredstvami tehnologij jelektronnogo obuchenija: Sb. statej (pp. 14-18). Moskva: MGPU.

Bartosh, D. K., Galskova, N. D., \& Harlamova, M. V. (2017). Jelektronnye tehnologii v sisteme obuchenija inostrannym jazykam: teorija i praktika: Uchebnoe posobie. Moskva: MGPU.

Bauer, R. (1999). Medienkompetenz der Lehrer/-innen: ein Baustein zur Professionalisierung des Lehrerberufes (oder wenn Schüler (oft) mehr wissen als ihre Lehrer). In F. Lehner \& 
U. Nikolaus (Hrsg.). Multimediales Lernen. Wiesbaden, Deutscher Universitäts-Verlag $\mathrm{GmbH}$.

Ezhikov, D. A. (2013). Metodika razvitija rechevyh umenij studentov na osnove sredstv sinhronnoj video-internet-kommunikacii (anglijskij jazyk, nejazykovoj vuz). Autoref. kand. diss. ped. n. Moskva.

Gulley, K. P. (2003). Pros and cons of computer technology in the classroom. Spring. Retrieved from https://in.nau.edu/wp-content/uploads/sites/135/2018/08/Pros-andCons-of-Computer-Technology-in-the-Classroom-ek.pdf

Helmke A., \& Weinert F. (1997). Bedingungsfaktoren schulischer Leistungen. In F. Weinert (Hrsg.). Enzyklopädie der Psychologie. Band 3. Psychologie des Unterrichts und der Schule. (pp. 71-176). Göttingen: Hogrefe.

Hughes, J. (2005). The role of teacher knowledge and learning experiences in forming technology-integrated pedagogy. In Journal of Technology and Teacher Education, $13 / 2,277-302$.

Kerres, M., \& Preussler, A., Schiefner-Rohs, M. (2013). Lernen mit Medien. In Grundlagen der praktischen Information und Dokumentation. Ed. by Rainer Kuhlen, Wolfgang Semar, Dietmar Strauch (Hrsg.). 6. Ausgabe. Berlin: Walter de Gruyter.

Kohenderfer, Ju. V. (2013). Metodika formirovanija inojazychnoj kommunikativnoj kompetencii uchashhihsja na osnove jazykovyh multimedijnyh programm (osnovnaja i starshhshaja shkola, nemeckij jazyk). Avtoref. kand. diss. ped. n. Moskva.

Koshelaeva, E. D. (2010). Metodika razvitija sociokulturnyh umenij studentov posredstvom socialnogo servisa "Viki" (anglijskij jazyk, jazykovoj vuz): Dis. kandidata ped. nauk. Moskva: MPGU.

Martiny, K. (2009). Der Einsatz von Neuen Medien im Fremdsprachenunterricht. Technische Universitaet Darmstadt. Retrieved from http://www.daf.tu-darmstadt.de/media/daf/ dateien/pdfs/studienarbeiten/martiny_persnlichedatenentfernt.pdf

Moser, H. (2001). Internet-Lernen: Nutzungsdefizite und Chancen. Pädagogisches Forum. Dezember 14.

Ovchinnikova, M. V., \& Akimova, N. V. (2009). Vozmozhnye puti integracii ochnogo $i$ distancionnogo obuchenija inostrannomu jazyku $v$ profilnyh klassah starshej shkoly. Moskva.

Paveleva, T. Ju. (2010). Razvitie umenij pismennoj rechi studentov sredstvami uchebnogo Internet - bloga (anglijskij jazyk, jazykovoj vuz). Avtoreferat dis. kand. ped. nauk. Tambov.

Petrisheva, N. S. (2011). Metodika formirovanija sociokulturnoj kompetencii studentov specialnosti "Jurisprudencija" posredstvom uchebnyh Internet-proektov (anglijskij jazyk): Avtoreferat kandidata pedagogicheskih nauk. Moskva: MGLU.

Platten, E. (2003). Chat-Tutoren im Didaktischen Chat-Raum - Sprachliche Hilfen und Moderation. In M. Legutke, \& D. Rösler (Hrsg.). Fremdsprachenlernen mit digitalen Medien. Tübingen: Gunter Narr Verlag.

Prensky, M. (2001). Digital Natives, Digital Immigrants. On the Horizon (MCB University Press, 9, 5, October). Retrieved from https://www.marcprensky.com/writing/Prensky\%20 -\%20Digital\%20Natives,\%20Digital\%20Immigrants\%20-\%20Part1.pdf

Robert, I. V. (2005). Osnovnye napravlenija informatizacii obrazovanija v otechestvennoj shkole. Vestnik moskovskogo gorodskogo universiteta. Informatika i informatizacija obrazovanija, 5, 106-114. 
Schäfner, P. (2009). E-Learning im Fremdsprachenunterricht. Beiträge zur Fremdsprachenvermittlung. Sonderheft 14, 7-17. Retrieved from http://rom-ld.rp.lo-net2. de/elearning/.ws_gen/3/Artikel_E-Learning_im_Fremdsprachenunterricht.pdf

Schelhowe, H. (2009). Kompetenzen in einer digital geprägten Kultur: Medienbildung für die Persönlichkeitsentwicklung, für die gesellschaftliche Teilhabe und für die Entwicklung von Ausbildungs- und Erwerbsfähigkeit. Referat Digitale Medien und Informationsinfrastruktur. Bonn, Berlin: Bundesministerium für Bildung und Forschung (BMBF).

Sheingold, K., Martin, L. M. W. \& Endreweit, M. E. (1987). Preparing urban teachers for the technological future. In R. Pea \& K. Scheingold (Eds.), Mirrors of the mind: Patterns of experience in educational computing. (pp. 67-85). Norwood, NJ: Ablex.

Stöcklin, N. (2012). Von analog zu digital: die neuen Herausforderungen für die Schule. In E. Blaschitz, G. Brandhofer, Ch. Nosko, \& G. Schwed (Hrsg.), Zukunft des Lernens. Wie digitale Medien Schule, Aus- und Weiterbildung verändern. Glückstadt: Hülsbusch, 57-74. Retrieved from https://www.fachportal-paedagogik.de/literatur/vollanzeige. html?FId=1019455\#vollanzeige

Sysoev, P. V. (2012). Informacionnye i kommunikacionnye tehnologii v obuchenii inostrannomu jazyku: teorija i praktika: monografija. Moskva: Glossa-Press.

Sysoev, P. V., \& Evstigneev, M. N. (2010). Metodika obuchenija inostrannomu jazyku s ispolzovaniem novyh informacionno-kommunikacionny Internet-tehnologij: uchebnometodicheskoe posobie dlja uchitelej, aspirantov i studentov. Rostov na Donu: Feniks; Moskva: Glossa-Press.

Urban-Woldron, H. (2008). Fachdidaktisch verwertbares Wissen aus der vergleichenden Analyse von Studien zum Lehren und Lernen mit neuen Medien. IMST Fonds. Universität Klagenfurt.

Zaec, T. V. (2017). Ispolzovanie jelektronnogo interaktivnogo uchebnogo posobija (JeIUP) po domashnemu chteniju na mladshih kursah bakalavriata v nejazykovom vuze (na primere nemeckogo jazyka) In Sozdanie virtualnogo mezhkulturnogo obrazovatelnogo prostranstva sredstvami tehnologij jelektronnogo obuchenija: Sbornik statej. (pp. 6975). Moskva: MGPU.

Zagvjazinskij, V. I. (2001). Teorija obuchenija: Sovremennaja interpretacija: Uchebnoe posobie dlja stud. vyssh. ped. ucheb, zavedenij. Moskva: Izdatel'skij centr Akademija. 